\title{
Comparative Study of Antioxidant Activity of Different Extracts and Essential Oil Compositions Obtained from Artemisia sieberi Besser using Two Different Methods
}

\author{
ZAHRA AGHAJANI $^{1 *}$, MARYAM AKHBARI ${ }^{2}$ and BAHAREH ESMAEILI ${ }^{3}$ \\ 1'Department of Chemistry, Qom Branch, Islamic Azad University, Qom, Iran. \\ ${ }^{2}$ Essential Oil Research Institute, University of Kashan, Kashan, Iran. \\ ${ }^{3}$ Department of chemistry, Shahr-e-Rey Branch, Islamic Azad University, Tehran, Iran. \\ ${ }^{*}$ Corresponding author E-mail: haj_aghajani@yahoo.com \\ http://dx.doi.org/10.13005/ojc/300121
}

(Received: December 10, 2013; Accepted: January 20, 2014)

\begin{abstract}
ABSTARACT
This study deals with essential oils of the aerial parts of Artemisia sieberi Besser which was obtained by hydrodistillation (HD) and simultaneous water steam distillation-organic solvent extraction (SDE) methods and compared regard to their components. The major compounds of the oil obtained by hydrodistillation were verbenol (16.09\%) and myristicin (13.76\%). However, by using SDE, E-epoxy ocimen $(14.02 \%)$ and verbenol $(13.93 \%)$ were detected as the major components. SDE obtained essential oil was very higher than that of hydrodistillation method based on the yield. Antioxidant activities of various extracts from A.sieberi were also evaluated via DPPH radical scavenging assay; total phenolic compounds were also measured using Folin-ciocalteu reagent. The results exhibited that, water extract of $A$.sieberi has considerable antioxidant activity and it seems that this activity drops off sharply with reducing polarity of extraction solvent.
\end{abstract}

Key words: Artemisia sieberi; essential oil; antioxidant; DPPH; total phenolic compounds.

\section{INTRODUCTION}

Artemisia sieberi Besser, belongs to the Asteraceae family, is a widely distributed plant in Iran ${ }^{1-2}$. In Iranian folk medicine, Artemisia sieberi is introduced to be useful for spasmolytic effects ${ }^{3-4}$, vermicide and also for strengthening stamina and relieving cold symptoms. A. sieberi oil like some other species of Artemisia has potential to be used as an insecticide ${ }^{5}$. Animal dermatophytosis and clinical improvement with $3 \%$ solution of $A$. sieberi oil have been observed which is in comparison with clotrimazole ${ }^{6}$. Antidiabetic, antimalarial and antimicrobial effects of this plant have been reported previously ${ }^{7-11}$.

As mentioned above, because of its medicinal properties, this plant is undoubtly a good candidate for evaluating phytochemicals or biological activities.

A couple of studies in the literature have reported composition of the essential oil of Artemisia sieberi, extracted by hydrodistillation method and 
also extraction using supercritical carbon dioxide from different locations of $\operatorname{Iran}^{12-17}$. It is clear that production of secondary metabolites in plants is firmly depended on ecological conditions ${ }^{18}$ and, in addition, yield of oil extraction and the chemical composition of the obtained essential oil may change as the method of extraction changes. According to the above descriptions and lack of enough reports about phytochemical and biological properties of this plant in the literature, this research focuses on comparative study on the chemical constituents of volatile oil obtained by SDE and general hydrodistillation extraction methods from $A$. siberi growing wild in Kashan, central Iran. Antioxidant activities of water, ethanol and chloroform extracts of this plant have also been assessed.

\section{EXPERIMENTAL}

\section{Plant materials}

The plants were collected from Karkas Mountains of Kashan, Iran, at an altitude about $1800 \mathrm{~m}$ in April 2010. The voucher specimens of the plant were confirmed in the Herbarium of Research Center of Barij Essence Pharmaceutical Company of Kashan (code: 1_108).

\section{Essential oil isolation}

The aerial parts of examined plants were dried in shadow at room temperature. Hydrodistillation and simultaneous water steam distillationorganic solvent extraction (SDE) methods ${ }^{17}$ were used in this study. The extracted oils were then dehydrated by anhydrous sodium sulphate, to yield $0.3 \%$ and $1.13 \%$ of brown-red oil respectively.

\section{GC-Mass analysis}

The isolated Essential oils were analyzed using GC/FID for quantitative analysis and GC/MS to qualitative analysis on a HEWLETT-PACKARD 6890 gas chromatograph coupled with a mass detector (HEWLETT-PACKARD model $6973 \mathrm{HP}$ ). HP-Innowax capillary column $(60 \mathrm{~m} \times 0.32 \mathrm{~mm}, 0.50 \mathrm{~mm}$ film thickness) was used as the oil analyser. The mass spectra were obtained by electron ionization at $70 \mathrm{eV}$. The oven temperature was programmed as follows: $80^{\circ} \mathrm{C}$ (3 min), $80-230^{\circ} \mathrm{C}\left(3^{\circ} \mathrm{C} / \mathrm{min}\right), 230^{\circ} \mathrm{C}(5 \mathrm{~min})$, $230-250^{\circ} \mathrm{C}\left(3^{\circ} \mathrm{C} / \mathrm{min}\right)$ and $250^{\circ} \mathrm{C}(10 \mathrm{~min})$.
The injection temperature was $250^{\circ} \mathrm{C}$. The carrier gas (helium) flow rate was $1 \mathrm{ml} / \mathrm{min}$. The sample $(1 \mu \mathrm{l})$ was injected with a split ratio of $1 / 90$. Retention indices were calculated for all components using a homologous series of n-alkanes injected in conditions equal to those of the samples. Identification of components of Eos was based on retention indices (RI) relative to $n$-alkanes and computer matching with the Wiley 275.L and Wiley7n.L libraries. Also, comparisons of the fragmentation pattern of the mass spectra were made with data published in the literature ${ }^{18}$.

\section{Preparation of extracts}

Thirty grams of the powdered aerial parts of the plant were soxhlet-extracted with $300 \mathrm{ml}$ solvent. Solvent removal using rotary evaporation and drying the residue using a vacuum oven at $50^{\circ} \mathrm{C}$ yielded $14.0 \% \mathrm{w} / \mathrm{w}$ of water, $14.0 \% \mathrm{w} / \mathrm{w}$ of ethanol and $9.5 \%$ $\mathrm{w} / \mathrm{w}$ of chloroform extracts with the colours brown, green and light green respectively. Extracts were kept in dark at $4^{\circ} \mathrm{C}$ until be tested.

\section{Antioxidant activity}

For evaluating antioxidant activities of samples, DPPH bleaching and total phenol measuring assays were used.

\section{DPPH bleaching assay}

In this assay the antioxidant activity was determined by measuring DPPH free radical scavenging ability.

To plot BHT standard curve, absorbance of DPPH methanol solution in the presence of various concentrations of BHT after $40 \mathrm{~min}$ in $517 \mathrm{~nm}$ was measured and inhibition of DPPH free radical in percent $(1 \%)$ was calculated as follows:

$\mathrm{I} \%=($ Ablank-Asample/Ablank $) \times 100$

Where Ablank is the absorbance of the control reaction, containing all reagents except the test compound. Inhibition percentage of the samples ( $1 \mathrm{mg} / \mathrm{ml}$ of water, ethanol and chloroform extracts) and BHT standard were calculated similarly and all tests were carried out in triplicate to improve accuracy. Ability of DPPH radical scavenging was calculated as $\%$. 


\section{Total phenol measuring}

Total phenolic constituents of the aforesaid extracts of $A$. sieberi were determined based on the absorbance values of the extract reacted with Folin-Ciocalteu reagent and compared the results with gallic acid as standard solution ${ }^{19}$ with slight modifications. This assay was carried out in order to obtain the total phenolic contents of the extracts according to the $\mu \mathrm{g}$ gallic acid equivalent (GAE) per $1 \mathrm{mg}$ of extract. For this purpose, a solution containing $1 \mathrm{mg}$ crude extract in ethanol was exposed to $1 \mathrm{ml}$ of Folin-Ciocalteu reagent in the presence of $3 \mathrm{ml}$ of a $2 \% \mathrm{Na}_{2} \mathrm{CO}_{3}$ in a $50 \mathrm{ml}$ volumetric balloon. The mixture was allowed to stand for $2 \mathrm{~h}$ with intermittent shaking (roughly every 30 minutes). Absorbance was measured at $760 \mathrm{~nm}$. The same procedure was repeated for different concentrations of standard gallic acid solutions (0-1000 $\mathrm{mg}$ per $0.1 \mathrm{ml})$. The equation for the standard curve obtained was found to be like eq. (1).

Absorbance $=0.0012 \times$ Gallic acid $(\mu \mathrm{g})+0.0033$

Gallic acid equivalent of the samples was calculated as $\mu \mathrm{g}$ of gallic acid per mg of sample.

\section{RESULTS AND DISCUSSION}

The yield of hydrodistillated essential oil (HDEO) was $0.3 \%$ for Artemisia sieberi Besser from Kashan in comparison with $1.13 \%$ which obtained from SDE prepared essential oil (SDEO) which is almost 4 times more than that of HDEO.

Table 1: essential oils compositions of Artemisia sieberi Besser aerial parts from Kashan, Iran

\begin{tabular}{|c|c|c|c|c|}
\hline No. & Compound Name & $\mathbf{R} \mathbf{l}^{\mathbf{c}}$ & Comp ${ }^{a} .(\%)$ & Comp $^{\mathrm{b}} .(\%$ \\
\hline 1. & Verbenene & 1151 & - & 1.38 \\
\hline 2. & 1,8 Cineole & 1235 & - & 0.14 \\
\hline 3. & Yomogi alcohol & 1397 & 5.21 & 6.68 \\
\hline 4. & Artemiseole & 1413 & 5391 & 10.41 \\
\hline 5. & $\beta$-Thujone & 1465 & - & 4.76 \\
\hline 6. & $\alpha$-Thujone & 1477 & 4.02 & 7.071 \\
\hline 7. & Artemisia alcohol & 1514 & 2.01 & 3.05 \\
\hline 8. & Camphor & 1549 & 1.09 & 9.03 \\
\hline 9. & trans-Chrysanthenyl acetate & 1602 & - & 1.12 \\
\hline 10. & Bornyl acetate & 1603 & 2.24 & 1.26 \\
\hline 11. & cis-Verbenol & 1673 & 16.09 & 14.15 \\
\hline 12. & $\alpha$-Phellandren-8-ol & 1679 & 7.44 & 4.98 \\
\hline 13. & Lavandulol & 1688 & 0.78 & - \\
\hline 14. & Borneol & 1721 & 6.61 & 2.11 \\
\hline 15. & cis-Chrysanthenol & 1765 & 1.83 & - \\
\hline 16. & E-Epoxy ocimen & 1847 & 9.77 & 14.24 \\
\hline 17. & p- Cymen-8-ol & 1865 & 0.92 & - \\
\hline 18. & CisCarvone Oxide & 1919 & 1.65 & - \\
\hline 19. & 2E-Hexenyl butanoate & 1936 & - & 2.66 \\
\hline 20. & Caryophyllene oxide & 2016 & 1.17 & - \\
\hline 21. & 2-Pentadecanone, 6,10,14-trimethyl- & 2144 & 1.35 & - \\
\hline 22. & Spathulenol & 2153 & 1.51 & 0.66 \\
\hline 23. & Eugenol & 2196 & 2.05 & 2.18 \\
\hline 24. & Thymol & 2207 & 1.86 & 0.63 \\
\hline 25. & 6-Methoxy-elemicin & 2231 & 1.51 & 0.56 \\
\hline 26. & Carvacrol & 2238 & 1.72 & 0.46 \\
\hline 27. & Elemicin & 2252 & 1.56 & 0.71 \\
\hline 28. & Myristicin & 2292 & 13.76 & 3.78 \\
\hline 29. & Apiole & 2518 & 5.00 & 1.37 \\
\hline
\end{tabular}


Table 2: Extraction yields and antioxidant activity of extracts of Artemisia siberi from Kashan, Iran

\begin{tabular}{lccc}
\hline Sample & $\begin{array}{c}\text { Yield of } \\
\text { extaction }\end{array}$ & $\begin{array}{c}\text { DPPH } \\
\%\end{array}$ & $\begin{array}{c}\text { Totalphenolics: Gallicacid } \\
\text { eq( } \boldsymbol{\mu g} / \mathbf{m g} \text { sample) }\end{array}$ \\
\hline Water extract & $14.0 \%$ & $69.00 \pm 0.40$ & $66.14 \pm 0.91$ \\
Ethanol extract & $14.0 \%$ & $55.73 \pm 1.00$ & $59.61 \pm 0.54$ \\
Choloroform extract & $9.5 \%$ & $13.47 \pm 0.92$ & $36.30 \pm 0.39$ \\
BHT & - & $87.10 \pm 0.82$ & - \\
\hline
\end{tabular}

Compositions of the essential oils were evaluated using GC-MS analysis. The major components in the HDEO were found to be verbenol $(16.09 \%)$, myristicin $(13.76 \%$,), E-epoxy ocimen $(9.77 \%)$ and $\alpha$-phellandren-8-ol (7.44\%). These are very different from the other reported components detected in $A$. siberi of other locations $(10,11,13)$ these components are also, very different from those of SDEO with E-epoxy ocimen (14.02 \%), verbenol (13.93\%), artemiseole $(10.25 \%)$ and camphor $(8.89 \%)$ as the majors. As can be seen, although total number of components detected in both mentioned essential oils were almost equal, their types and percentages were very different (Table 1); for example some compounds such as lavandulol $(0.78 \%)$, cis chrysanthenol $(1.83 \%)$, p- cymen-8-ol $(0.92 \%)$, cis carvone oxide $(1.65 \%)$ caryophyllene oxide (1.17\%) and 6,10,14-trimethyl 2-pentadecanone, (1.35\%) detected in HDEO, were not seen in SDEO. On the other hand, verbenene $(1.36 \%), 1,8$ cineole $(0.14 \%), \beta$-thujone $(4.69 \%)$, trans-chrysanthenyl acetate (1.10\%) and 2E-hexenyl butanoate $(2.62 \%)$ which were found in SDEO, were not seen in HDEO.

Compounds such as myristicin and verbenol observed in the mentioned plant have been reported to be the most important contributors in insecticiding effects of the essential oil of Artemisia species.
Comparing these results, it can be revealed that method of essential oil isolation has a significant role on extraction yield, type and amount of extracted compounds.

Antioxidant activities, based on DPPH free-radical assay, for water, ethanol and chloroform extracts (Table 2) exhibit higher activity of water extract in the order of water> ethanol > chloroform. Total phenolic contents of these extracts also obey this order, but the differences are not as significant as antioxidant activities. Considering these findings and the yields of extraction, it seems that water as a safe and eco-friendly solvent, which is used locally in domestic consumptions, is the best solvent for extracting bioactive materials as far as antioxidant activity is concerned.

\section{CONCLUSION}

According to these results it needs to point out that the extraction solvent and method has generally a significant influence on properties and amount of active components of the plant extracts. In addition, as it is observed in this research, the yield of essential oil extraction for SDE method is much higher than general hydrodistillation technique; therefore, it can be concluded that the use of this especial techniques can be useful particularly for plants with low-content essential oil, such as Artemisia species.

\section{REFERENCES}

1. Mozaffarian V. A dictionary of Iranian plants names, Tehran, Iran: Farhang Moaser (1998).

2. Ghahraman A. Color Flora of Iran, Tehran, Iran: Forest and Rangelands Resarch Institute
(1997).

3. Zargari A. Medicinal Plants, 6th ed. Tehran, Iran: Tehran University Press (1996).

4. Mirza M, Sefidkon F \& Ahmadi L. Natural Essence, Extraction, Identification, Tehran, 
Iran: Research Institute of Forest and Rangelands (1998).

5. Negahban M, Moharramipour S, Sefidkon F. Insecticidal activity of essential oil from Artemisia sieberi Beser against three storedproduct insects, J Stored Prod Res, 43: 123128 (2007).

6. Khosravi A.R, Mahmoudi M \& Shirani D. Evaluation of the use of Artemisia sieberi essence for treatment of cats and dogs with dermatophytosis, J Facul Vet Med, 58: 293-5 (2003).

7. Mahboubi M, Farzin N. Antimicrobial activity of Artemisia sieberi essential oil from central Iran, Iran J Microbiol, 1(2): 43-48 (2009).

8. Irshad F, Manis K \& Aburjai T, Antidiabetic effect of eesential oil from Artemisia sieberi growing in Jordan, Pak. J. Biol. Sci, 13(9): 423-430 (2010).

9. Nahrevanian $\mathrm{H}$, Sheykhkanlooye Milan B, Kazemi M, Hajhosseini, R, Soleymani Mashhadi S \& Nahrevanian S. Antimalarial effects of Iranian flora Artemisia sieberi on Plasmodium berghei In Vivo in mice and phytochemistry analysis of its herbal extracts, Malar Res Treat, Article ID 727032, 8 pages (2012).

10. Weyerstahl S, SchneiderS, Marschall $\mathrm{H}$ and Rustaiyan A, The essential oil of Artemisia sieberi Bess. Flavor Frag J, 8:139-145 (1993).

11. Prasad and S.P. Sati, Orient J. Chem., 28(1): 591-593 (2012).

12. Zidane, F. Aouniti, A. Tahani, M.L. Fauconnier and A. Elbachiri, Orient J. Chem., 29(4): 13191324 (2013).

13. Sefidkon F, Jalili A \& Mirhaji T, Essential oil composition of three Artemisia sp. from Iran. Flavor Frag J, 7: 150-152 (2002).
14. Azarnivand $\mathrm{H}$. Investigation of botanical and ecological characteristics of Artemisia sieberi and Artemisia oucheri in the Southern Aspect of Alborz, M.Sc. Thesis, Tehran University, Iran (2003).

15. Farzaneh $\mathrm{M}$, Ghorbani-Ghouzhdi $\mathrm{H}$, Ghorbani $M$ \& Hadian J, Composition and antifungal activity of essential oil of Artemisia sieberi bess. on soil-borne phytopathogens, Pak. J. Biol. Sci, 9: 1979-1982 (2006).

16. Ghaemi E.O, Heshmati G.A, Behmanesh B, Ahmadi A.R, Rezaei M.B, Bakhshandeh Nosrat S \& Mazandarani M. Chemical composition and antibacterial activity from essential oil of Artemisia sieberi Besser subsp. Sieberi in North of Iran, Asian J Plant Sci, 6(3): 562-564 (2007).

17. Ghasemi E, Yamini Y, Bahramifar N, Sefidkon $\mathrm{F}$, Comparative analysis of the oil and supercritical $\mathrm{CO} 2$ extract of Artemisia sieberi, J Food Eng, 79(1): 306-311 (2007).

18. Omidbeigi R, Production and Processing of Medicinal Plants, 1st Edn., Razavy Ghods Astan Press, Mashad, pp: 347 (2005).

19. Filek G, Bergamini M \& Lindner W, Steam distillation-solvent extraction, a selective sample enrichment technique for gas chromatographic-electron-capture detection of organochlorine compounds in milk powder and other milk products. J. Chromatogr. A, 712: 355-364 (1995).

20. Adams R P, Identification of EO components by gas chromatography/mass spectroscopy, Carol Stream IL: Allured Publishing Co (2001).

21. Slinkard K, Singleton VL, Total phenol analysis: automation and comparison with manual methods, Am J Enol Viticult, 28: 49-55 (1997). 